\title{
Contrasting conifer species productivity in relation to soil carbon, nitrogen and phosphorus stoichiometry of British Columbia perhumid rainforests
}

\author{
John Marty Kranabetter ${ }^{1}$, Ariana Sholinder ${ }^{2}$, and Louise de Montigny ${ }^{3}$ \\ ${ }^{1}$ British Columbia Ministry of Forests, Lands and Natural Resource Operations, P.O. Box 9536, \\ Stn Prov Govt, Victoria, BC V8W 9C4, Canada \\ ${ }^{2}$ Centre for Forest Biology, University of Victoria, P.O. Box 3020, Stn CSC, Victoria, BC V8W 3N5, Canada \\ ${ }^{3}$ British Columbia Ministry of Forests, Lands and Natural Resource Operations, P.O. Box 9512, \\ Stn Prov Govt, Victoria, BC V8W 9C2, Canada
}

Correspondence: John Marty Kranabetter (marty.kranabetter@gov.bc.ca)

Received: 1 October 2019 - Discussion started: 23 October 2019

Revised: 1 February 2020 - Accepted: 4 February 2020 - Published: 6 March 2020

\begin{abstract}
Temperate rainforest soils of the Pacific Northwest are often carbon $(\mathrm{C})$ rich and encompass a wide range of fertility, reflecting varying nitrogen $(\mathrm{N})$ and phosphorus $(\mathrm{P})$ availability. Soil resource stoichiometry $(\mathrm{C}: \mathrm{N}: \mathrm{P})$ may provide an effective measure of site nutrient status and help refine species-dependent patterns in forest productivity across edaphic gradients. We determined mineral soil and forest floor nutrient concentrations across very wet (perhumid) rainforest sites of southwestern Vancouver Island (Canada) and employed soil element ratios as covariates in a longterm planting density trial to test their utility in defining basal area growth response of four conifer species. There were strong positive correlations in mineral soil $\mathrm{C}, \mathrm{N}$, and organic $\mathrm{P}\left(\mathrm{P}_{\mathrm{O}}\right)$ concentrations and close alignment in $\mathrm{C}: \mathrm{N}$ and $\mathrm{C}: \mathrm{P}_{\mathrm{O}}$ both among and between substrates. Stand basal area after 5 decades was best reflected by mineral soil and forest floor $\mathrm{C}: \mathrm{N}$, but in either case included a significant speciessoil interaction. The conifers with ectomycorrhizal fungi had diverging growth responses displaying either competitive (Picea sitchensis) or stress-tolerant (Tsuga heterophylla, Pseudotsuga menziesii) attributes, in contrast to a more generalist response by an arbuscular mycorrhizal tree (Thuja plicata). Despite the consistent patterns in organic matter quality, we found no evidence for increased foliar $\mathrm{P}$ concentrations with declining element ratios $\left(\mathrm{C}: \mathrm{P}_{\mathrm{o}}\right.$ or $\left.\mathrm{C}: \mathrm{P}_{\text {total }}\right)$ as we did for $\mathrm{N}$. The often high $\mathrm{C}: \mathrm{P}_{\mathrm{o}}$ ratios (as much as 3000 ) of these soils may reflect a stronger immobilization sink for $\mathrm{P}$
\end{abstract}

than $\mathrm{N}$, which, along with ongoing sorption of $\mathrm{PO}_{4}^{-}$, could limit the utility of $\mathrm{C}: \mathrm{P}_{\mathrm{o}}$ or $\mathrm{N}: \mathrm{P}_{\mathrm{o}}$ to adequately reflect $\mathrm{P}$ supply. The dynamics and availability of soil $\mathrm{P}$ to trees, particularly as $\mathrm{P}_{\mathrm{o}}$, deserves greater attention, as many perhumid rainforests were co-limited by $\mathrm{N}$ and $\mathrm{P}$, or, in some stands, possibly $\mathrm{P}$ alone.

\section{Introduction}

One of the largest global expanses of temperate rainforest (approximately 25 million ha) is located along the Pacific coast of northwestern North America (DellaSala et al., 2011), an area renowned for towering, conifer-dominated forests of extraordinary productivity and longevity (Waring and Franklin, 1979; Smithwick et al., 2002; Keith et al., 2009). Carpenter et al. (2014) highlighted the high diversity of soil types across this region and some key attributes related to soil carbon $(\mathrm{C})$, nitrogen $(\mathrm{N})$ and phosphorus $(\mathrm{P})$ status of these forests. Most notably, temperate rainforests often have substantial accumulations of organic matter at the soil surface (forest floors) and in mineral horizons that rank among the highest in global soil C stocks (Sun et al., 2004; Homann et al., 2005; McNicol et al., 2019). Secondly, the N concentrations of certain soils can be extremely high which, along with ample moisture, underpins the tremendous productivity of many forest stands (Perakis et al., 2006; Littke et al., 
2011; Kranabetter et al., 2015). In contrast, areas with low relief and imperfect drainage can have deep organic soils and scrubby, less productive forests with very limited $\mathrm{N}$ availability (Sajedi et al., 2012; Kranabetter et al., 2013; Bisbing and D'Amore, 2018). Thirdly, intensive weathering under high rainfall combined with acidic leachate derived from coniferous vegetation has accelerated soil podzolization (Singleton and Lavkulich, 1987; Sanborn et al., 2011), resulting in limited supplies of $\mathrm{P}$ in some areas that likely co-limit forest growth (Preston and Trofymow, 2000; Blevins et al., 2006; Mainwaring et al., 2014; Kranabetter et al., 2019a). Temperate rainforests with these combined attributes in soil organic matter, $\mathrm{N}$ and $\mathrm{P}$ may lack analogues to forest ecosystems elsewhere (Carpenter et al., 2014). Consequently, a more detailed understanding of soil nutrient limitations and dynamics would better support land management decisions regarding wood production, $\mathrm{C}$ budgets and conservation priorities.

Resource stoichiometry $(\mathrm{C}: \mathrm{N}: \mathrm{P})$ of soils may be one avenue in which the combined constraints of $\mathrm{N}$ and $\mathrm{P}$ on ecosystem productivity can be effectively evaluated (Zechmeister-Boltenstern et al., 2015; Spohn, 2016). An essential premise of ecological stoichiometry is that rates of $\mathrm{N}$ and $\mathrm{P}$ immobilization or mineralization in soils are closely linked to microbial biomass stoichiometry (Manzoni et al., 2010; Mooshammer et al., 2014; Zechmeister-Bolenstern et al., 2015). Element ratios $(C: N$ and $C: P)$ reach a threshold where microbes shift from being $\mathrm{C}$-limited to $\mathrm{N}$ - or $\mathrm{P}$-limited, and consequently the mineralization and release of nutrients for plant uptake during decomposition should increase with declining $\mathrm{C}: \mathrm{N}$ or $\mathrm{C}: \mathrm{P}$ of soil organic matter (e.g., Saggar et al., 1998; Prescott et al., 2000a; Heuck and Spohn, 2016). In addition, N:P ratios of organic matter can indicate the relative extent of $\mathrm{N}$ and $\mathrm{P}$ limitations on decomposition and primary productivity, as $\mathrm{N}: \mathrm{P}$ tends to increase in older or well-weathered soils where $\mathrm{P}$ constraints might supersede those of N (Wardle et al., 2004; Güsewell and Gessner, 2009). In comparison to nutrient stocks (e.g., $\mathrm{kg} \mathrm{Nha}^{-1}$ ), which require measures of soil bulk density, coarse fragment content and organic horizon thickness, resource stoichiometry presents a potentially simpler interpretation of nutrient dynamics across diverse landscapes (Bui and Henderson, 2013; Littke et al., 2014; Van Sundert et al., 2020). Further details on the nature of soil organic matter across temperate rainforests would contribute to this comprehensive depiction of global nutrient dynamics (Tipping et al., 2016; Achat et al., 2016).

Baseline relationships in soil resource stoichiometry and ecosystem productivity should also consider the interaction with tree species. Temperate rainforests of the Pacific Northwest are exceptional because of the prevalence of evergreen conifer species, many of which host ectomycorrhizal fungi (ECM) (Tsuga, Abies, Picea, Pseudotsuga and Pinus spp.) or, alternatively, arbuscular (ARB) mycorrhiza (Thuja and Sequoia spp.). Waring and Franklin (1979) postulated that most deciduous hardwood species were extirpated from the
Pacific Northwest by the early Pleistocene, as the climate favoured evergreen trees and their ability to photosynthesize during fall and winter months instead of through the driest parts of the growing season. As a result, interspecific competition and adaptive traits related to soil fertility have arisen primarily between the coniferous species of this landscape (Lacourse, 2009; Coates et al., 2013) and exclude, with minor exceptions (Acer, Prunus), the deciduous ARB species that can dominate soils of high fertility (low $\mathrm{C}: \mathrm{N}$ ) elsewhere (Phillips et al., 2013; Soudzilovskaia et al., 2015; Lin et al., 2017). It should also be recognized that tree species, in turn, can influence soil $\mathrm{C}$ and nutrient cycling through differences in litter (foliar and root) quality and mycorrhizal habit, which could eventually manifest as distinct speciessoil stoichiometry relationships (Prescott, 2002; Augusto et al., 2002; Cools et al., 2014). Quantifying both the species response to soil fertility and possible feedback of tree species on soil resources is challenging in uncontrolled settings, and consequently well-replicated, long-term field trials may be the best avenue for better understanding these interactions (Binkley, 1995; Augusto et al., 2002).

The quintessential rainforests along the outer west coast of British Columbia are classified as "perhumid", with relatively high summer rainfall, cool summers and transient snowpacks (DellaSala et al., 2011). In the early 1960s, the British Columbia Forest Service established a multi-species planting density trial across several perhumid rainforest sites of southwestern Vancouver Island (Omule, 1988). The study sites encompassed a considerable range in forest productivity that provided a valuable opportunity to examine ECM and ARB conifer species growth and nutrition in relation to soil $\mathrm{C}, \mathrm{N}$ and $\mathrm{P}$ stoichiometry. We follow the convention of Tipping et al. (2016) in this analysis by utilizing organic $\mathrm{P}\left(\mathrm{P}_{\mathrm{o}}\right)$ in stoichiometry comparisons (rather than total $\mathrm{P}$ ) to focus more directly on properties of soil organic matter. The element enrichment of organic matter was compared by correlations among $C: N, C: P_{o}$ and $N: P_{o}$ (Manzoni et al., 2010; Tipping et al., 2016) for each substrate because of the typically stark differences in the $\mathrm{C}$ density of forest floors compared to mineral soils (e.g., $50 \%$ vs. $5 \% \mathrm{C}$, respectively). In addition, we relied upon foliar $\mathrm{N}$ and $\mathrm{P}$ concentrations for the more conventional interpretation of stand nutrition (e.g., Carter, 1992) rather than foliar C-nutrient ratios. The objectives of our study were to (1) document the range and covariation in $\mathrm{C}, \mathrm{N}$, and $\mathrm{P}_{\mathrm{O}}$ concentrations and element ratios across a variety of sites and between mineral soil and forest floor substrates; (2) test the utility of soil $\mathrm{C}: \mathrm{N}, \mathrm{C}: \mathrm{P}_{\mathrm{o}}$, and $\mathrm{N}: \mathrm{P}_{\mathrm{o}}$ ratios as explanatory variables in relation to forest productivity response; and (3) quantify any divergence in conifer growth response to soil fertility gradients among ECM (Tsuga, Picea, Pseudotsuga) and ARB (Thuja) tree species. 


\section{Methods}

\subsection{Site and study descriptions} elevations $(<300 \mathrm{~m})$ at seven locations in the Coastal Western Hemlock very wet maritime subzone (CWHvm; Green and Klinka, 1994) of western Vancouver Island (between Port Renfrew and Bamfield, British Columbia), where mean annual precipitation averages almost $3400 \mathrm{~mm}$ (Table 1). These areas supported old-growth forests before logging took place between 1958 and 1960, and cutblocks were subsequently slashburned in 1961 . The study areas encompassed a wide range in soil nutrient and moisture regimes (Green and Klinka, 1994): steep, well-drained upland sites with poor to average nutrients; imperfectly drained, nutrient-poor sites on modest slopes; steep, nutrient-rich sites on base-rich colluvial material; and low-lying, nutrient-rich sites with seepage (Supplement Table S1). Soils were derived from glacial morainal, fluvial or colluvial deposits, with sandy loam to loam textures, moderate stone content, and well-defined $\mathrm{Bf}$ or Bfh horizons (Humo-Ferric or Ferro-Humic Podzols, respectively; Soil Classification Working Group, 1998).

The four conifer species utilized in the study are native to the Pacific Northwest: western hemlock (Tsuga heterophylla [Raf.] Sarg.), Sitka spruce (Picea sitchensis [Bong.] Carr.), coastal Douglas fir (Pseudotsuga menziesii var. menziesii [Mirb.] Franco) and western red cedar (Thuja plicata Donn ex D. Don in Lamb.). Single seedlots for each species were collected from the CWHvm on Vancouver Island and planted as $2+0$ bare root stock in April of 1962 (Omule, 1988). The three planting density treatments were $2.7 \mathrm{~m} \times 2.7 \mathrm{~m}\left(1329\right.$ stems ha $\left.^{-1}\right), 3.7 \mathrm{~m} \times 3.7 \mathrm{~m}$ $\left(748\right.$ stems ha $\left.^{-1}\right)$ and $4.6 \mathrm{~m} \times 4.6 \mathrm{~m}\left(479 \mathrm{stems} \mathrm{ha}^{-1}\right)$. Each plot consisted of 81 trees planted in rows of 9 , with the inner $7 \times 7$ rows (49 trees) tagged for remeasurement. Plot size ranged proportionally with planting density $(0.037$, 0.066 , and $0.102 \mathrm{ha}$, respectively). All four conifer species were planted at every site, but the density treatment was not fully replicated across the study installations; San Juan and Branch 136 had only the $2.7 \mathrm{~m}$ spacing $(n=4)$, while WC1000 lacked the $4.6 \mathrm{~m}$ spacing $(n=8$; Table 1$)$.

\subsection{Soil and tree measures}

Individual tree heights and diameters at $1.3 \mathrm{~m}$ were measured most recently in 2014 (52 years in age). In May of 2018 we sampled the upper soil profile (i.e., the predominant rooting zone) for chemical properties mirroring the methodology of Kranabetter et al. (2019a). Forest floors were cut and removed over a $10 \mathrm{~cm}$ diameter area to the mineral soil interface, and the forest floor depth was noted at each microsite. Mineral soils were sampled to a $20 \mathrm{~cm}$ depth with a stony soil auger. Subsamples from 12 random microsites were composited into three forest floor and three mineral soil samples per
The planting density trial (EP571) was established along low

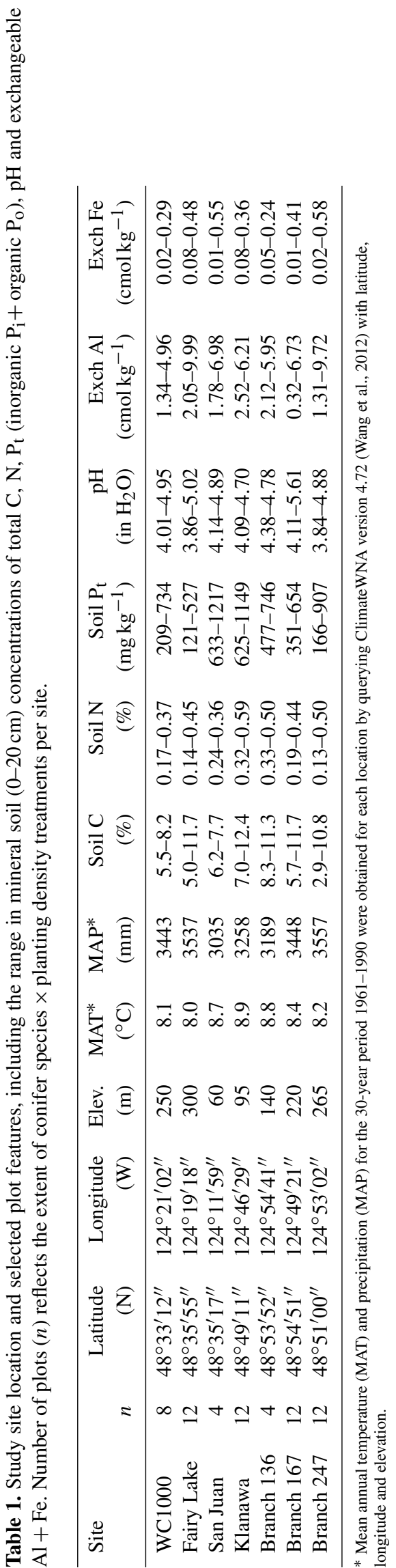


plot (an occasional plot had very thin forest floors, $<1 \mathrm{~cm}$, so in those cases we took only one or two bulked samples). Soils were air-dried, ground and sieved to $2 \mathrm{~mm}$ for chemical analysis. Foliar samples were collected at the end of the growing season (mid-November 2018) by searching each plot for fresh branches that had broken off during recent storms. We strove to obtain needles from current-year foliage off at least 12 separate branches and combined these into three samples per plot. Foliar samples were oven-dried at $60^{\circ} \mathrm{C}$ for $24 \mathrm{~h}$ and then ground for nutrient analysis.

Total $\mathrm{C}$ and $\mathrm{N}$ concentrations of soil and foliage were measured using combustion elemental analysis with a Fisons/Carlo-Erba NA-1500 NCS analyzer (Thermo Fisher Scientific, Waltham, MA, USA) (Carter and Gregorich, 2008). Mineral soil and forest floors were finely ground to $<0.15 \mathrm{~mm}$ (100 mesh sieve) before combustion analysis. Total $\mathrm{P}\left(\mathrm{P}_{\mathrm{t}}=\right.$ inorganic $\left.\mathrm{P}_{\mathrm{i}}+\operatorname{organic} \mathrm{P}_{\mathrm{o}}\right)$ of mineral soils and forest floors was determined by an ignition method using sulfuric acid and an UV/visible spectrophotometer (O'Halloran and Cade-Menum, 2008). Foliar P was determined by inductively coupled plasma atomic emission spectroscopy (Teledyne Leeman Labs, Hudson, NH) following microwave digestion.

\subsection{Statistics}

Element ratios $\left(\mathrm{C}: \mathrm{N}, \mathrm{C}: \mathrm{P}_{\mathrm{o}}\right.$ and $\mathrm{N}: \mathrm{P}_{\mathrm{o}}$ as molar ratios) were determined on each soil subsample and then averaged by plot for statistical analysis. The covariation among average concentrations of $\mathrm{C}, \mathrm{N}, \mathrm{P}_{\mathrm{o}}$ and their element ratios was determined by pair-wise Pearson correlation coefficients (SAS Institute Inc., 2014). Element ratios as a proportional rather than absolute metric are potentially prone to spurious correlations (Jackson and Somers, 1991) so our purpose was to aid in data visualization and confirm direction of the relationships (Tipping et al., 2016), rather than implying causation. Conifer productivity was assessed by stand basal area $\left(\mathrm{m}^{2} \mathrm{ha}^{-1}\right.$ of live trees in 2014). Scaling factors in the conversion to hectares (to account for differences in plot size) were 27.1 for $2.7 \mathrm{~m}$ spacing, 15.3 for $3.7 \mathrm{~m}$ spacing and 9.8 for $4.6 \mathrm{~m}$ spacing.

The experimental treatment effects (species and spacing) on soil nutrient concentrations, forest floor depth, stand basal area and stocking (stems ha ${ }^{-1}$ ) were tested by fitting separate linear mixed-effect models in SAS (mixed procedure; method $=$ REML, Restricted Maximum Likelihood) (SAS Institute, 2014), with site set as a random effect. We examined the relationships between stand basal area and soils by including each element ratio as a single continuous variable in the model, along with the full set of interactions. The interaction terms spacing $\times$ soil and species $\times$ spacing $\times$ soil were consistently nonsignificant for all soil variables tested, thus the final models were refitted with these terms removed. Goodness of fit for the model was evaluated by the F statistic of each parameter, as well as by the lowest overall model
Akaike information criterion (AIC). Model outputs were also assessed graphically by plotting the observed dependent variable vs. predicted values to ensure a relationship close to 1 : 1. Foliar N, P and N : P in relation to species, spacing and soil element ratios were examined in the same manner, but the final models were refitted without species $\times$ spacing, spacing $\times$ soil, species $\times$ soil and species $\times$ spacing $\times$ soil interaction terms as they were consistently nonsignificant for all soil variables tested.

\section{Results}

\subsection{Soil nutrient concentrations and resource stoichiometry by substrate}

We found a considerable range in nutrient concentrations (e.g., $0.15-0.60 \% \mathrm{~N}$; Table 1) and strong, positive correlations among $\mathrm{C}, \mathrm{N}$ and $\mathrm{P}_{\mathrm{o}}$ for mineral soils (Pearson $r>0.7$ ) across these temperate rainforest sites (Table 2, Fig. 1). Inorganic $\mathrm{P}_{\mathrm{i}}$ concentrations of mineral soils were relatively limited, often $<200 \mathrm{mg} \mathrm{kg}^{-1}$, which was substantially less than the contribution of $\mathrm{P}_{\mathrm{o}}$ to total $\mathrm{P}$ for a majority of plots (53 of 64 plots had $\mathrm{P}_{\mathrm{o}}>70 \%$ of $\mathrm{P}_{\mathrm{t}}$ ). In addition to limited $\mathrm{P}_{\mathrm{i}}$, the extent of soil podzolization was reflected by typically low $\mathrm{pH}$ and elevated concentrations of exchangeable $\mathrm{Al}$ and Fe (Table 1). Forest floors averaged $5.5 \mathrm{~cm}$ in depth (standard error, SE, 0.6) overall and displayed a narrower range in $\mathrm{C}(31 \% \mathrm{C}-55 \% \mathrm{C}$, average $=46 \% \mathrm{C}$, SE 0.7$)$ but also exhibited a significant positive correlation between $\mathrm{N}$ and $\mathrm{P}_{\mathrm{O}}$ concentrations (Table 2). Similar to mineral substrates, the concentrations of inorganic $P_{i}$ (average $110 \mathrm{mg} \mathrm{kg}^{-1}$, SE 5.8) were uniformly low in forest floors, in contrast to $\mathrm{P}_{\mathrm{o}}$ (average $970 \mathrm{mg} \mathrm{kg}^{-1}$, SE 71), and consequently contributed only a small proportion of total $\mathrm{P}\left(\mathrm{P}_{\mathrm{o}} \sim 90 \%\right.$ of $\mathrm{P}_{\mathrm{t}}$ in forest floors).

$\mathrm{C}: \mathrm{N}$ ratios of the mineral soils became significantly narrower (declining from 44 to 23) with increasing \% C (Table 2, Fig. 2a), similar to $C: P_{o}$ (range approx. 300-1200) (Table 2). In contrast, $\mathrm{C}: \mathrm{N}$ of forest floors widened with increasing $\% \mathrm{C}$ (Fig. 2b, Table 2) but nevertheless $\mathrm{C}: \mathrm{N}$ of both substrates were well aligned across sites $(r=0.85, p<0.001$; Fig. 3a). The same symmetry in element ratios between substrates was found with $\mathrm{C}: \mathrm{P}_{\mathrm{o}}(r=0.78, p<0.001)$ and, to a lesser degree, $\mathrm{N}: \mathrm{P}_{\mathrm{o}}(r=0.58, p<0.001)$ (Fig. 3b, c). In all cases the relationships in element ratios were not $1: 1$ as the organic horizons were less concentrated than mineral soils (e.g., a forest floor $\mathrm{C}: \mathrm{N}$ of 40 would be matched with a mineral soil $\mathrm{C}: \mathrm{N}$ of 30 , on average; Fig. 3a). Lastly, there was typically a high degree of correlation $(r>0.7)$ in element ratios within a substrate, such as $\mathrm{C}: \mathrm{N}$ vs. $\mathrm{C}: \mathrm{P}_{\mathrm{o}}$, for both mineral soils and forest floors (Table 2).

At this juncture in plantation age (52 years), we found no evidence that conifer species or planting density had an effect on mineral soil nutrient concentrations or ratios (for species, $p=0.99$ for $\mathrm{C}: \mathrm{N}, p=0.48$ for $\mathrm{C}: \mathrm{P}_{\mathrm{o}}$, and $p=0.35$ for 
Table 2. Pearson correlation $r$ and $p$ values (in brackets, $<0.05$ in bold) among total $\mathrm{C}, \mathrm{N}, \mathrm{P}_{\mathrm{O}}$ concentrations and associated molar element ratios of the mineral soil $(0-20 \mathrm{~cm})$ and forest floor.

\begin{tabular}{|c|c|c|c|c|c|}
\hline & $\mathrm{N}$ & $\mathrm{P}_{\mathrm{O}}$ & $\mathrm{C}: \mathrm{N}$ & $\mathrm{C}: \mathrm{P}_{\mathrm{O}}$ & $\mathrm{N}: \mathrm{P}_{\mathrm{O}}$ \\
\hline \multicolumn{6}{|c|}{ Mineral soil } \\
\hline $\mathrm{C}$ & $0.92(<\mathbf{0 . 0 0 1})$ & $0.71(<\mathbf{0 . 0 0 1})$ & $-0.48(<\mathbf{0 . 0 0 1})$ & $-0.36(\mathbf{0 . 0 0 4})$ & $-0.21(0.101)$ \\
\hline $\mathrm{N}$ & - & $0.87(<\mathbf{0 . 0 0 1})$ & $-0.75(<\mathbf{0 . 0 0 1})$ & $-0.59(<\mathbf{0 . 0 0 1})$ & $-0.38(\mathbf{0 . 0 0 2})$ \\
\hline $\mathrm{P}_{\mathrm{O}}$ & & - & $-0.77(<\mathbf{0 . 0 0 1})$ & $-0.82(<\mathbf{0 . 0 0 1})$ & $-0.73(<\mathbf{0 . 0 0 1})$ \\
\hline $\mathrm{C}: \mathrm{N}$ & & & - & $0.81(<\mathbf{0 . 0 0 1})$ & $0.55(\mathbf{0 . 0 0 1})$ \\
\hline $\mathrm{C}: \mathrm{P}_{\mathrm{O}}$ & & & & - & $0.93(<\mathbf{0 . 0 0 1})$ \\
\hline
\end{tabular}

\begin{tabular}{|c|c|c|c|c|c|}
\hline \multicolumn{6}{|c|}{ Forest floor } \\
\hline $\mathrm{C}$ & $-0.01(0.91)$ & $-0.32(\mathbf{0 . 0 1 1})$ & $0.51(<\mathbf{0 . 0 0 1})$ & $0.61(<\mathbf{0 . 0 0 1})$ & $0.52(<\mathbf{0 . 0 0 1})$ \\
\hline $\mathrm{N}$ & - & $0.74(<\mathbf{0 . 0 0 1})$ & $-0.84(<\mathbf{0 . 0 0 1})$ & $-0.59(<\mathbf{0 . 0 0 1})$ & $-0.34(\mathbf{0 . 0 0 6})$ \\
\hline $\mathrm{P}_{\mathrm{o}}$ & & - & $-0.71(<\mathbf{0 . 0 0 1})$ & $-0.84(<\mathbf{0 . 0 0 1})$ & $-0.82(<\mathbf{0 . 0 0 1})$ \\
\hline $\mathrm{C}: \mathrm{N}$ & & & - & $0.77(<\mathbf{0 . 0 0 1})$ & $0.48(<\mathbf{0 . 0 0 1})$ \\
\hline $\mathrm{C}: \mathrm{P}_{\mathrm{O}}$ & & & & - & $0.91(<\mathbf{0 . 0 0 1})$ \\
\hline
\end{tabular}

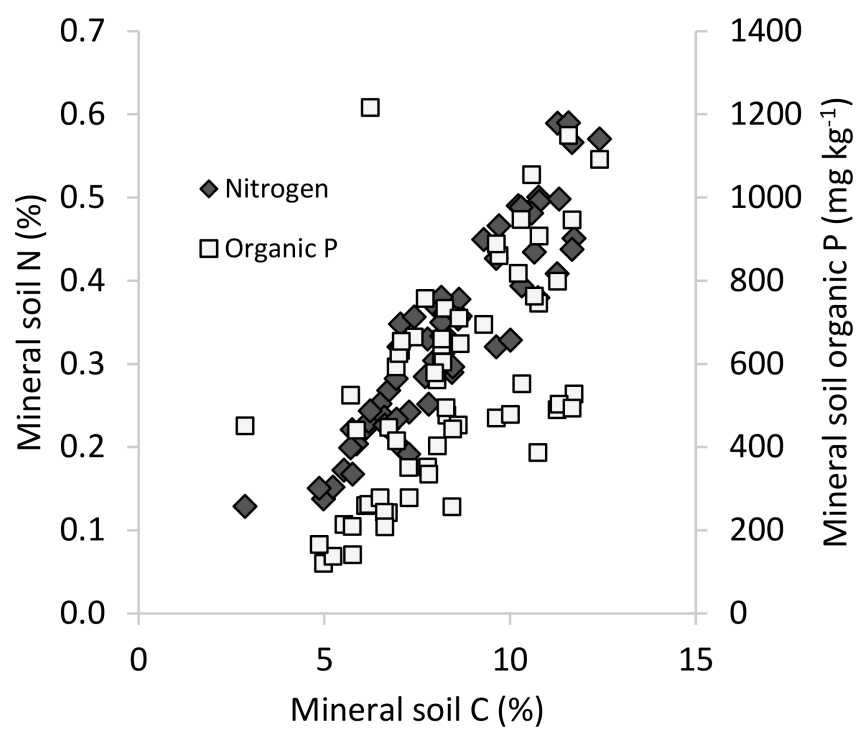

Figure 1. Mineral soil $(0-20 \mathrm{~cm}) \mathrm{N}$ and $\mathrm{P}_{\mathrm{O}}$ concentrations in relation to mineral soil $\mathrm{C}$ across the study sites.

$\mathrm{N}: \mathrm{P}_{\mathrm{o}}$; for spacing, $p=0.61$ for $\mathrm{C}: \mathrm{N}, p=0.65$ for $\mathrm{C}: \mathrm{P}_{\mathrm{o}}$, and $p=0.73$ for $\left.\mathrm{N}: \mathrm{P}_{\mathrm{o}}\right)$. There was, however, a slight difference detected in $\mathrm{N} \%$ of forest floors with species $(p=$ 0.034). Forest floor $\mathrm{N}$ concentration under $P$. menziesii averaged $1.52 \% \mathrm{~N}$ (SE 0.06), which was slightly greater than the other three species (combined average $1.35 \% \mathrm{~N}$ ), although forest floors also tended to be thinner under $P$. menziesii $(4.7 \mathrm{~cm}$, SE 0.8 , on average, compared to $5.9 \mathrm{~cm}$ for the other three species; $p=0.13$ ). Despite the modification in $\mathrm{N}$ concentrations under $P$. menziesii, this species effect did not extend to element ratios of forest floors (for species, $p=0.30$ for $\mathrm{C}: \mathrm{N}, p=0.97$ for $\mathrm{C}: \mathrm{P}_{\mathrm{o}}$, and $p=0.53$ for $\mathrm{N}: \mathrm{P}_{\mathrm{o}}$; for spacing, $p=0.25$ for $\mathrm{C}: \mathrm{N}, p=0.42$ for $\mathrm{C}: \mathrm{P}_{\mathrm{o}}$, and $p=0.25$ for $\mathrm{N}: \mathrm{P}_{\mathrm{o}}$ ).

\subsection{Stand productivity in relation to soil resource stoichiometry}

Stand density (stems ha ${ }^{-1}$ ) in 2014 was well aligned with initial planting spacing, and there were significant differences among conifer species in stocking (Supplement Fig. S1). Thuja plicata had the least mortality (average $80 \%$ survival), followed by $P$. sitchensis $(76 \%), T$. heterophylla (71\%) and then P. menziesii (65\%). With the original study design we could only detect a significant effect of spacing on stand basal area $(2.7 \mathrm{~m}$ spacing $=70,3.7 \mathrm{~m}=61$ and $4.6 \mathrm{~m}=53 \mathrm{~m}^{2} \mathrm{ha}^{-1}$, on average) (Table 3 ). Including a soil element ratio of either substrate as a covariate in the analysis provided further details on species response, particularly with $\mathrm{C}: \mathrm{N}$ (Table 3). Stand basal area was well aligned with mineral soil and forest floor $\mathrm{C}: \mathrm{N}$ for all four species, with a significant species interaction due to the sharper gains in $P$. sitchensis basal area with decreasing $\mathrm{C}: \mathrm{N}$ (Figs. $4 \mathrm{a}, \mathrm{b}$ and S2). Soil $C: P_{o}$ and $N: P_{o}$ were also mostly significant covariates in the analysis of basal area, but neither ratio invoked the same degree of species response (i.e., lower F values) or significant species $\times$ soil interactions, and both models had poorer AIC scores than $\mathrm{C}: \mathrm{N}$ (Table 3). For comparison we also tested $\mathrm{C}: \mathrm{P}_{\mathrm{t}}$ and $\mathrm{N}: \mathrm{P}_{\mathrm{t}}$ of each substrate against basal area but found virtually identical model outputs as $C: P_{0}$ and $\mathrm{N}: \mathrm{P}_{\mathrm{O}}$ (data not shown).

\subsection{Foliar nutrition in relation to soil resource stoichiometry}

Foliage collections were not entirely successful as a few plots, particularly under $P$. sitchensis, had insufficient branches to obtain three composite subsamples $(n=167$ from a target of 192 subsamples and with two P. sitchensis plots removed from the analysis). Carbon concentrations of the foliage were very uniform, averaging 52.9 (SE 0.17) 

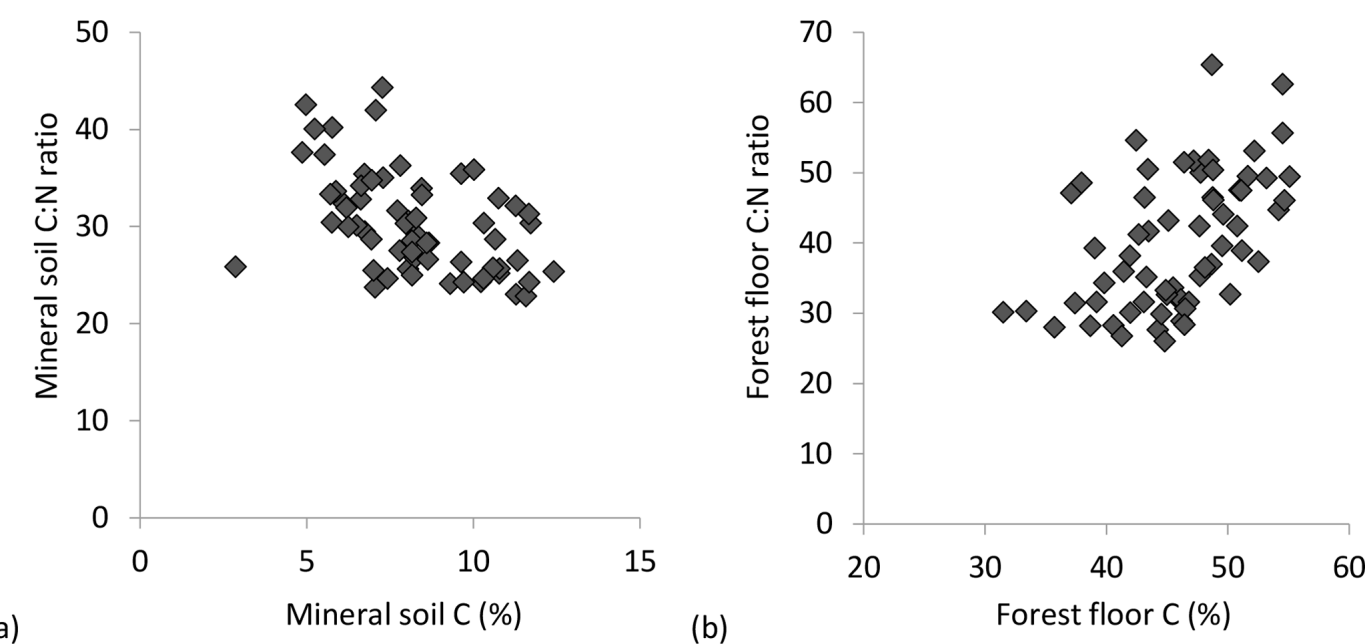

Figure 2. Trends in $\mathrm{C}: \mathrm{N}$ molar ratios of (a) mineral soil $(0-20 \mathrm{~cm})$ and (b) forest floors in relation to substrate $\mathrm{C}$ concentrations.

Table 3. Conifer species basal area $\left(\mathrm{m}^{2} \mathrm{ha}^{-1}\right)$ in 2014 (stand age 52 years) in relation to planting density $\left(1329,748\right.$ and 479 stems ha ${ }^{-1}$ ) and mineral soil $(0-20 \mathrm{~cm}$ ) or forest floor resource stoichiometry (as molar ratios; $p$ values $<0.05$ in bold; AIC fit values shown in italics).

\begin{tabular}{|c|c|c|c|c|c|c|c|c|c|}
\hline & \multirow[b]{2}{*}{ Df } & \multicolumn{2}{|c|}{ No soil variable } & \multicolumn{2}{|c|}{ Soil C : N } & \multicolumn{2}{|c|}{ Soil $\mathrm{C}: \mathrm{P}_{\mathrm{O}}$} & \multicolumn{2}{|c|}{ Soil $N: P_{O}$} \\
\hline & & $F$ value & $p$ value & $F$ value & $p$ value & $F$ value & $p$ value & $F$ value & $p$ value \\
\hline \multicolumn{10}{|l|}{ Mineral soil } \\
\hline Species & 3 & 2.12 & 0.110 & 4.60 & 0.007 & 2.11 & 0.113 & 1.09 & 0.363 \\
\hline Spacing & 2 & 7.12 & 0.002 & 11.94 & 0.001 & 10.06 & 0.001 & 7.88 & 0.001 \\
\hline Species $\times$ spacing & 6 & 0.72 & 0.634 & 0.91 & 0.495 & 0.72 & 0.632 & 0.54 & 0.774 \\
\hline Soil variable & 1 & $\mathrm{n} / \mathrm{a}$ & & 20.85 & 0.001 & 15.15 & 0.001 & 6.61 & 0.014 \\
\hline Soil $\times$ species & 3 & & & 3.75 & 0.018 & 1.27 & 0.296 & 0.82 & 0.491 \\
\hline AIC fit & & 450.2 & & 422.8 & & 460.0 & & 437.4 & \\
\hline \multicolumn{10}{|l|}{ Forest floor } \\
\hline Species & 3 & \multirow{6}{*}{\multicolumn{2}{|c|}{ Same as above }} & 3.97 & 0.014 & 2.11 & 0.114 & 1.29 & 0.290 \\
\hline Spacing & 2 & & & 10.92 & 0.001 & 7.29 & 0.002 & 6.80 & 0.003 \\
\hline Species $\times$ spacing & 6 & & & 0.82 & 0.559 & 0.51 & 0.799 & 0.46 & 0.818 \\
\hline Soil variable & 1 & & & 14.49 & 0.001 & 7.62 & 0.009 & 3.15 & 0.083 \\
\hline Soil $\times$ species & 3 & & & 3.01 & 0.041 & 0.94 & 0.431 & 0.77 & 0.547 \\
\hline AIC fit & & & & 420.7 & & 463.7 & & 435.9 & \\
\hline
\end{tabular}

n/a: not applicable.

for T. plicata, 52.3 for $P$. menziesii (0.17), 52.3 for $T$. heterophylla (0.18) and $51.9(0.19)$ for $P$. sitchensis. We were able to demonstrate an overall gain in foliar $\mathrm{N}$ with declining soil $\mathrm{C}: \mathrm{N}$ ratio, both for mineral and forest floor substrates, as well as a significant difference in foliar $\mathrm{N}$ among species due to the enhanced nutrition of $P$. sitchensis (Table 4; Fig. 5a; note that species $\times$ soil interaction $p=0.538$ for mineral soil and $p=0.305$ for forest floor). In contrast, there was no relationship between foliar $\mathrm{P}$ and $\mathrm{C}: \mathrm{P}_{\mathrm{o}}$ ratio for either substrate (Table 4, Fig. 5b; species $\times$ soil interaction $p=0.533$ for mineral soil and $p=0.561$ for forest floor). The better predictor of foliar $\mathrm{P}$ was instead the concentration of $\mathrm{P}_{\mathrm{i}}$ in soils, again with significant differences among species largely due to $P$. sitchensis (Table 4; Fig. S3; species $\times$ soil interaction $p=0.468$ for mineral soil, $p=0.425$ for forest floor). We also tested soil $\mathrm{P}_{\mathrm{t}}$ and $\mathrm{P}_{\mathrm{o}}$ concentrations in relation to foliar $\mathrm{P}$ but neither of these attributes were significant (for $\mathrm{P}_{\mathrm{t}}$, $p=0.41$ for forest floors and $p=0.12$ for mineral soil; for $\mathrm{P}_{\mathrm{o}}, p=0.94$ for mineral soil and $p=0.61$ for forest floors). Foliar N : P ratios across the plots averaged 19.5 (SE 0.8) for T. plicata, 18.2 (SE 0.8) for P. menziesii, 20.6 (SE 0.8) for T. heterophylla and 17.4 (SE 1.1) for P. sitchensis. We were unable to find a significant relationship between foliar $\mathrm{N}: \mathrm{P}$ and soil $\mathrm{N}: \mathrm{P}_{\mathrm{o}}$ for either substrate (Table 4). 


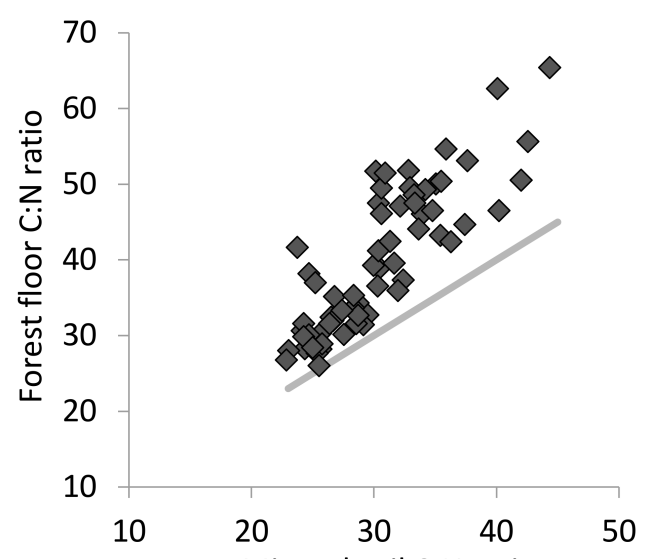

(a)

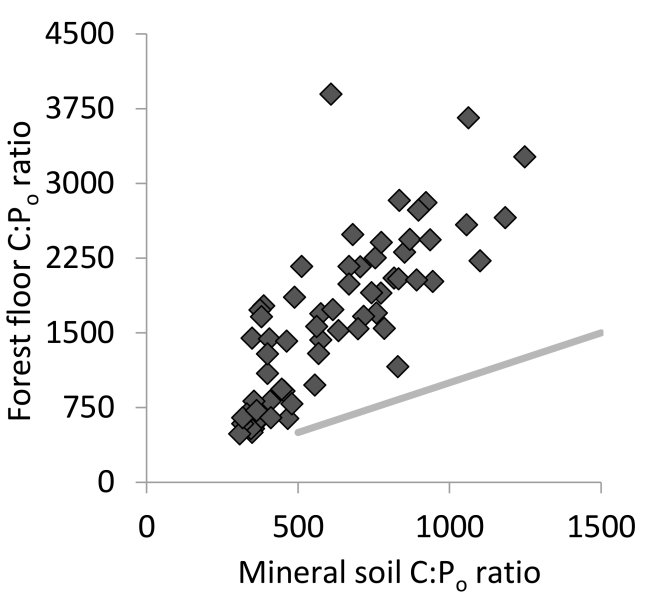

(b)

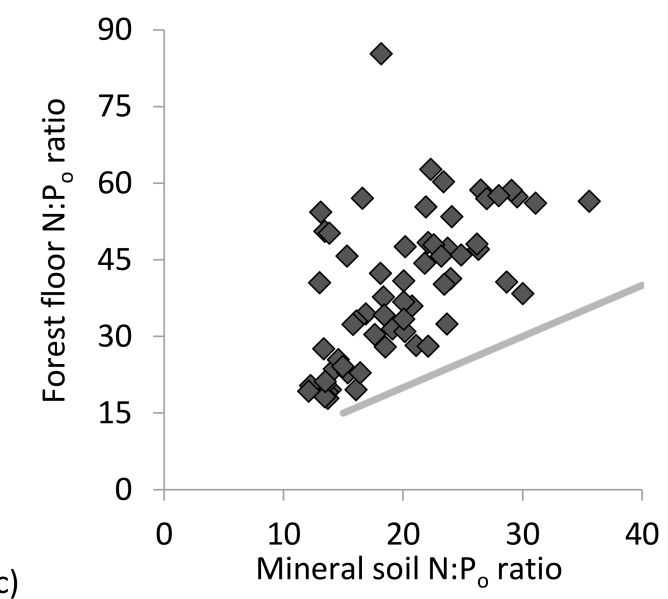

Figure 3. Correlation in resource stoichiometry for (a) $\mathrm{C}: \mathrm{N}$ molar ratio, (b) $\mathrm{C}: \mathrm{P}_{\mathrm{O}}$ molar ratio and (c) $\mathrm{N}: \mathrm{P}_{\mathrm{O}}$ molar ratio between mineral soil and forest floor substrates. A $1: 1$ relationship is depicted by the gray lines.
Table 4. Conifer species foliar nitrogen $(\mathrm{N})$ and phosphorus $(\mathrm{P})$ concentrations and molar $\mathrm{N}: \mathrm{P}$ ratios in relation to planting density $\left(1329,748\right.$ and 479 stems ha $\left.^{-1}\right)$ and mineral soil $(0-20 \mathrm{~cm})$ or forest floor resource stoichiometry (as molar ratio; $p$ values $<0.05$ in bold).

\begin{tabular}{|c|c|c|c|c|c|}
\hline & \multicolumn{3}{|c|}{ Mineral soil } & \multicolumn{2}{|c|}{ Forest floor } \\
\hline & Df & $F$ value & $p$ value & $F$ value & $p$ value \\
\hline \multicolumn{6}{|l|}{ Foliar N\% } \\
\hline Species & 3 & 9.32 & $<0.001$ & 7.72 & 0.001 \\
\hline Spacing & 2 & 0.39 & 0.677 & 0.97 & 0.387 \\
\hline Soil C:N & 1 & 8.13 & 0.006 & 19.16 & $<0.001$ \\
\hline \multicolumn{6}{|l|}{ Foliar P\% } \\
\hline Species & 3 & 12.56 & $<0.001$ & 11.94 & $<0.001$ \\
\hline Spacing & 2 & 0.32 & 0.729 & 0.36 & 0.703 \\
\hline Soil $C: P_{0}$ & 1 & 2.00 & 0.164 & 0.01 & 0.984 \\
\hline \multicolumn{6}{|l|}{ Foliar P\% } \\
\hline Species & 3 & 11.00 & $<0.001$ & 12.59 & $<0.001$ \\
\hline Spacing & 2 & 0.91 & 0.408 & 0.70 & 0.503 \\
\hline Soil $P_{i}$ & 1 & 13.45 & 0.001 & 6.76 & 0.012 \\
\hline \multicolumn{6}{|l|}{ Foliar N : P } \\
\hline Species & 3 & 5.02 & 0.004 & 4.21 & 0.010 \\
\hline Spacing & 2 & 1.15 & 0.324 & 1.10 & 0.340 \\
\hline Soil $N: P_{O}$ & 1 & 2.10 & 0.154 & 0.61 & 0.439 \\
\hline
\end{tabular}

\section{Discussion}

\subsection{Organic matter quality and conifer species productivity}

Our results provide further details on baseline nutrition and resource stoichiometry for soils of perhumid rainforests along the southwest coast of British Columbia and complement studies of temperate rainforests in the Southern Hemisphere (Parfitt et al., 2005; Turner et al., 2012). Soil C and $\mathrm{N}$ concentrations were at times very high (up to $12 \% \mathrm{C}$ and $0.6 \% \mathrm{~N}$ for mineral soil), as has been reported previously across this region (Carpenter et al., 2014; Kranabetter, 2019; McNichol et al., 2019), while $P_{i}$ was for the most part notably limited $\left(<200 \mathrm{mg} \mathrm{kg}^{-1}\right)$ in comparison to less weathered soils on the drier east side of Vancouver Island (Kranabetter et al., 2019a). The intense rainfall, acidic leachate (from coniferous vegetation) and (at some sites) possible $\mathrm{NO}_{3}^{-}$losses (Perakis et al,. 2013) have combined to reduce soil $\mathrm{pH}$ and enhance the sorption of $\mathrm{P}_{\mathrm{i}}$ with reactive (Fe and $\mathrm{Al}$ oxides) soil components (a sink-driven $\mathrm{P}$ limitation; Vitousek et al., 2010). Some differences in parent materials (e.g., colluvial slope, fluvial terrace, morainal till) may also have contributed to the inherent range in $\mathrm{P}$ content of these soils (Kranabetter and Banner, 2000). The high degree of positive correlations in $\mathrm{C}, \mathrm{N}$ and $\mathrm{P}_{\mathrm{o}}$ concentrations for min- 

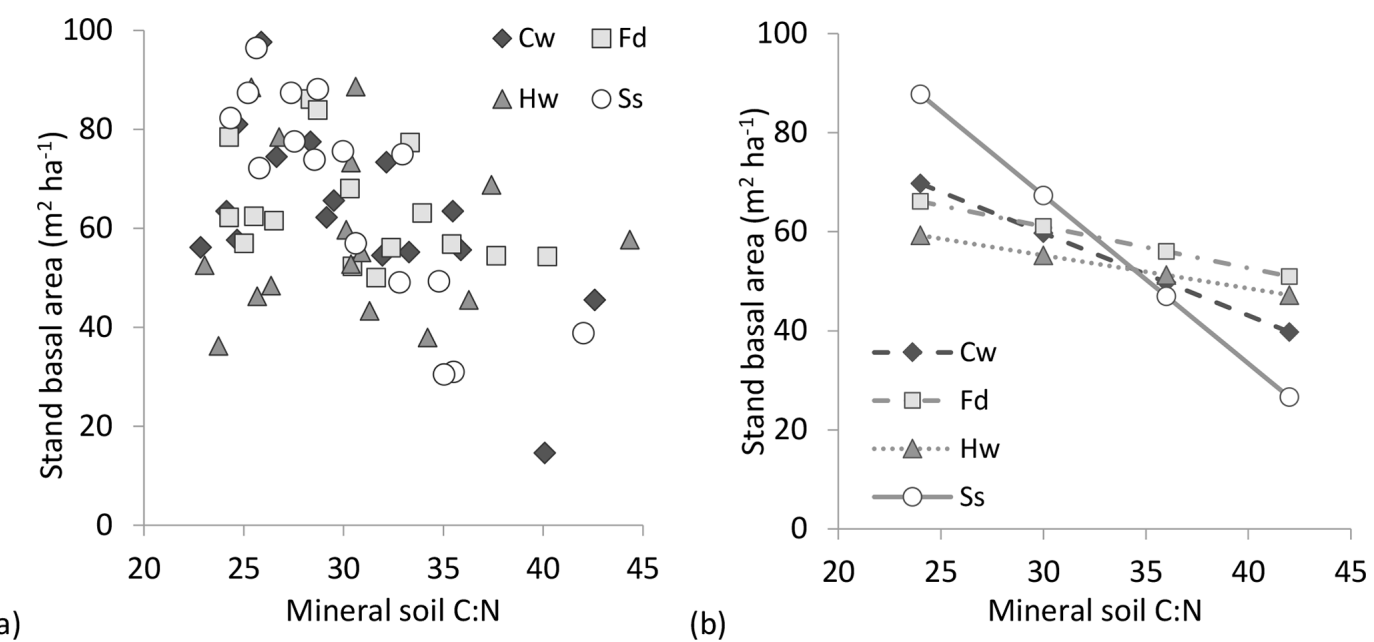

Figure 4. (a) Basal area by species in relation to mineral soil $\mathrm{C}: \mathrm{N}$ molar ratio (all planting densities included) and (b) linear regressions between stand basal area and mineral soil $\mathrm{C}: \mathrm{N}$, fitted by spacing, species and species $\times$ soil interactions (output averaged across planting density; species $\times$ soil $\left.\mathrm{C}: \mathrm{N} p=0.009, R^{2}=0.56\right)$. Slope of the $\mathrm{C}: \mathrm{N}$ regression was steepest for Picea sitchensis (Ss; -3.40$)$, followed by Thuja plicata $(\mathrm{Cw} ;-1.67)$, Pseudotsuga menziesii $(\mathrm{Fd} ;-0.84)$ and Tsuga heterophylla $(\mathrm{Hw} ;-0.70)$.
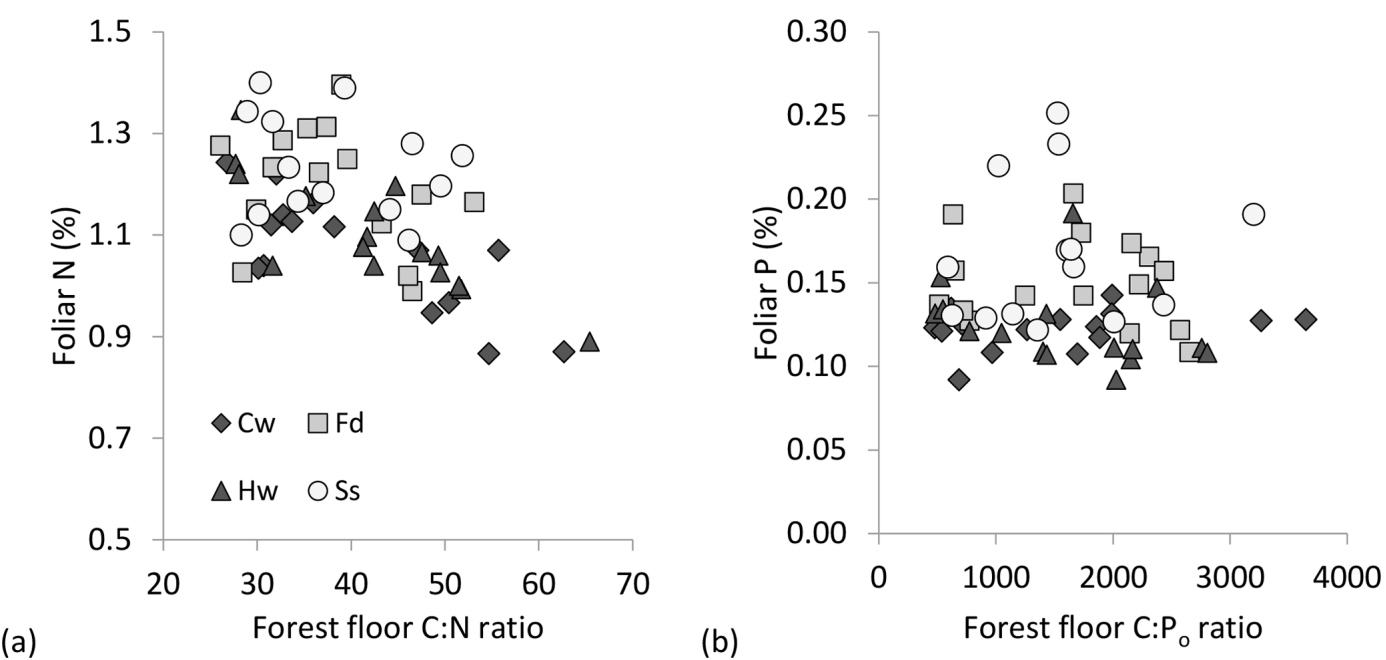

Figure 5. (a) Foliar $\mathrm{N}(\%)$ in relation to forest floor $\mathrm{C}: \mathrm{N}$ molar ratio and (b) foliar $\mathrm{P}(\%)$ in relation to forest floor $\mathrm{C}: \mathrm{P}_{\mathrm{o}}$ ratio: Thuja plicata (western red cedar $=\mathrm{Cw}$; Pseudotsuga menziesii $($ Douglas fir $)=\mathrm{Fd}$; Tsuga heterophylla $($ western hemlock $)=\mathrm{Hw} ;$ Picea sitchensis $($ Sitka spruce $)=$ Ss.

eral soils (and between $\mathrm{N}$ and $\mathrm{P}_{\mathrm{o}}$ for forest floors) was consistent with coniferous forests in Oregon (Perakis et al., 2013) and global datasets of soil organic matter (Xu et al., 2013; Tipping et al., 2016). Somewhat surprisingly we did not find evidence for decoupling of $\mathrm{P}_{\mathrm{o}}$ from organic matter as suggested by Yang and Post (2011) for highly weathered soils. Nevertheless, we surmise from the generally low soil $\mathrm{P}_{\mathrm{i}}$ concentrations, modest to high deficiencies in foliar $\mathrm{P}(0.10 \%-$ $0.15 \%$; Carter, 1992) for a large number of $\operatorname{stands}^{1}$ and el-

\footnotetext{
${ }^{1}$ Note that $P$. menziesii, $T$. heterophylla and $T$. plicata averaged $0.20 \% \mathrm{P}$ in less weathered soils of eastern Vancouver Island (Kranabetter et al., 2019a and unpublished data).
}

evated range (16-25) in foliar $\mathrm{N}: \mathrm{P}$ (greater than a hypothesized threshold of 14 to delineate $\mathrm{N}$-only deficiencies; Reich and Oleksyn, 2004) that these perhumid rainforests were often limited by $\mathrm{N}$ and $\mathrm{P}$ together (Blevins et al., 2006), or, in some stands, possibly $\mathrm{P}$ alone. The dynamics and availability of soil $\mathrm{P}$ to trees, particularly $\mathrm{P}_{\mathrm{o}}$, is challenging to reconcile given such strong and consistent patterns in soil organic matter quality.

The clear relationship between mineral soil and forest floor $\mathrm{C}: \mathrm{N}$ with stand productivity and foliar $\mathrm{N}$ was consistent with many other biomes (Littke et al., 2014; Alberti et al., 2015; Van Sundert et al., 2018) and affirms the widely recognized relationship of increasing $\mathrm{N}$ availability with declining soil 
$\mathrm{C}: \mathrm{N}$ (Booth et al., 2005). In contrast, $\mathrm{C}: \mathrm{P}_{\mathrm{o}}$ and $\mathrm{N}: \mathrm{P}_{\mathrm{o}}$ were less aligned with species growth response (and likely only significant as a surrogate for $\mathrm{C}: \mathrm{N}$ ) and not a significant predictor of foliar $\mathrm{P}$, despite the expectation of positive correlations in net $\mathrm{N}$ and $\mathrm{P}$ mineralization rates (Heuck and Spohn, 2016). Estimates of a critical $C: P_{o}$ for gross $P$ mineralization of leaf litter range from 1400 to 1800 (Mooshammer et al., 2012; Heuck and Spohn, 2016), but thresholds for forest floor horizons and mineral soil are likely much lower (perhaps $<500$; Saggar et al., 1998; Heuck and Spohn, 2016). The substrate distinction is important, as very few of our study sites had $\mathrm{C}: \mathrm{P}_{\mathrm{o}}$ ratios $<500$, suggesting pervasive, low-quality organic matter in regards to $P$. Furthermore, the element ratios of saprotrophic fungi, as key decomposers, in these perhumid rainforests averaged 120 and 10 for $\mathrm{C}: \mathrm{P}$ and $\mathrm{C}: \mathrm{N}$, respectively (Kranabetter et al., 2019a), which when compared to soil organic matter would indicate a greater elemental imbalance for P, especially in forest floors (Mooshammer et al., 2014). The biotic (microbes, plants) competition for $\mathrm{P}$ is also very likely exacerbated by abiotic competition for phosphate $\left(\mathrm{PO}_{4}^{-}\right)$via sorption to $\mathrm{Fe}$ and $\mathrm{Al}$ oxides, much more so than would be present for $\mathrm{NH}_{4}^{+}$or $\mathrm{NO}_{3}^{-}$(Olander and Vitousek, 2004). A greater sink strength via immobilization and sorption for $\mathrm{PO}_{4}^{-}$would require conifers to bypass mineralization of $\mathrm{P}$ by decomposers to some degree and instead access organic P more directly for uptake. A concurrent study of extracellular enzyme activity associated with ECM roots of $P$. menziesii has revealed substantial increases in P-acquiring enzymes (Justin Meeds, personal communication, 2019) that are likely acting upon the orthophosphate monoesters and diesters of organic P (Cade-Menum et al., 2000; Preston and Trofymow, 2000). Despite the expected contribution of $\mathrm{P}_{\mathrm{o}}$ to forest nutrition, however, we found it more effective to gauge $\mathrm{P}$ availability through soil $\mathrm{P}_{\mathrm{i}}$ concentrations (as the only significant correlate with foliar P), but other methods may prove to be more sensitive as a measure of plant-available $\mathrm{P}_{\mathrm{o}}$ (DeLuca et al., 2015; Darch et al., 2016).

One unique aspect of soil organic matter found here was a decrease in mineral soil $\mathrm{C}: \mathrm{N}$ and $\mathrm{C}: \mathrm{P}_{\mathrm{O}}$ ratios with increasing soil $\mathrm{C} \%$ (Fig. 2a), in contrast to the inverse relationships described by Tipping et al. (2016). This may reflect the significant legacy of $\mathrm{N}$-fixing red alder (Alnus rubra) in coastal forest ecosystems, which has been found to promote soil $\mathrm{C}$ sequestration and $\mathrm{P}$ mobilization while simultaneously adding high-quality (low $\mathrm{C}: \mathrm{N}$ ) litter (Binkley, 2005; Perakis and Pett-Ridge, 2019). A second key source of N-rich litter could be from epiphytic cyanolichens and cyanobacteriabryophyte associations (Antoine, 2004; Lindo and Whiteley, 2011). Canopy lichens and bryophytes are noteworthy in low-frequency disturbance ecosystems such as rainforests because they produce a steady input of $\mathrm{N}$ while growing independently of the soil environment (Menge and Hedin, 2009). Red alder, in comparison, is an early seral species that can be hindered in its establishment and vigour by low $\mathrm{P}_{\mathrm{i}}$ availability (Brown et al., 2011; Kranabetter et al., 2013). Hedin et al. (2009) described a similar N paradox in tropical forests and proposed $\mathrm{N}$-fixing epiphytes as one mechanism that allows soil $\mathrm{N}$ regimes to increase despite soil $\mathrm{P}_{\mathrm{i}}$ deficiencies or physiological downregulation of $\mathrm{N}$-fixation in high soil $\mathrm{N}$ environments.

\subsection{Conifer species interactions by ARB and ECM mycorrhizal guild}

The more significant differences in species productivity in relation to soil $\mathrm{C}: \mathrm{N}$ were among the $\mathrm{ECM}$ species rather than solely between mycorrhizal types. Tsuga heterophylla and $P$. menziesii had the most limited increase in basal area with declining $\mathrm{C}: \mathrm{N}$, a finding that was similar for these species in correlations of site index with organic matter quality across a broader region of the US northwest (Edmonds and Chappel, 2004). These two conifers would be considered relatively stress tolerant under the Competitors-Stress tolerators-Ruderals (C-S-R) model (Hodgson et al., 1999) as their growth on high $\mathrm{C}: \mathrm{N}$ soils outperformed that of either P. sitchensis or T. plicata. Picea sitchensis, in contrast, would clearly be a strong competitor, as exemplified by the impressive linear increase in biomass with declining soil C:N. Perakis and Sinkhorn (2011) found P. menziesii productivity plateaued with increasing $\mathrm{N}$ mineralization rates, but this relationship with $\mathrm{N}$ supply may be species-dependent and not necessarily apply to $P$. sitchensis. A possible functional trait related to this growth response is the low capacity of ECM roots of P. menziesii to maximize uptake of $\mathrm{NO}_{3}^{-}$, as would be in plentiful supply on these richer soils (Prescott et al., 2000b; Perakis et al., 2006), but whether P. sitchensis ECM roots would perform any differently has not been established (Boczulak et al., 2014; Hawkins and Kranabetter, 2017). As an aside, we noted some naturally regenerated Abies amabilis within the study areas that had the same girth as $P$. sitchensis, so it is likely Abies would be an equally competitive member of these rainforest ecosystems. Thuja plicata, as the only ARB tree species in the trial, was intermediate in growth response to soil $\mathrm{C}: \mathrm{N}$ and displayed no particular advantage in foliar $\mathrm{N}$ or $\mathrm{P}$ over the ECM conifers. Thuja plicata is recognized to have a wide ecological amplitude, from highly productive to very nutrient-poor or wet sites (Antos et al., 2016), and thus would fit well within a generalist or intermediate C-S strategy. The coexistence of ARB and ECM conifers affirms each mycorrhizal type is competent in the acquisition of nutrients from organic and inorganic sources (Hodge, 2017), and the contrasting patterns in productivity emphasize a diversity of traits within mycorrhizal guilds rather than a simple dichotomy in the distribution of ARB and ECM trees between $\mathrm{N}$-rich and $\mathrm{N}$-poor soils (Koele et al., 2012; Dickie et al., 2014). 


\subsection{Conifer species effects on soil organic matter quality}

After 5 decades the possibility of tree species effects on soil nutritional status is also worth considering. Enhanced N inputs via foliar litter are considered a positive reinforcement in sustaining soil fertility (Prescott, 2002), which would be consistent with the overall trend in foliar $\mathrm{N}$ across this productivity gradient. It was interesting to note that correlations between substrates for $\mathrm{C}: \mathrm{N}$ were closer to a $1: 1$ relationship than $\mathrm{C}: \mathrm{P}_{\mathrm{o}}$, indicating that $\mathrm{P}$ cycling through litterfall has been greatly impeded in comparison to $\mathrm{N}$. The small increase in forest floor $\mathrm{N}$ concentrations under $P$. menziesii may reflect slightly better litter quality (lower lignin content) and potentially faster decomposition rates for this species (Vesterdal and Raulund-Rasmussen, 1998; Thomas and Prescott, 2000). Overall, however, there were no clear differences in element ratios of either forest floors or mineral soils by tree species, which leads us to conclude these conifers lack substantial enough differences in leaf or root litter to have more profoundly and consistently diverged from inherent soil conditions. The glaciated landscape along Vancouver Island has been in the current iteration of temperate perhumid rainforests for at least 7500 years (Brown and Hebda, 2002; Lacourse, 2005), during which time the various site drivers (e.g., drainage, slope, soil mineralogy, vegetation) have collectively produced the very wide disparity in soil fertility found today. It would undoubtedly take a very sizable influence of tree species on $\mathrm{C}, \mathrm{N}$ or $\mathrm{P}$ cycling to overcome the inertia of site type in such complex terrain (Prescott et al., 2000b). For example, an ecologically minor shift in forest floor $\mathrm{C}: \mathrm{N}$ from 50 to 40 (equivalent to an average increase in foliar $\mathrm{N}$ from $1.17 \%$ to $1.23 \%$; Fig. 5a), would require a gain of approximately $200 \mathrm{~kg} \mathrm{ha}^{-1}$ in $\mathrm{N}$ (based on a depth of $5 \mathrm{~cm}$ and bulk density of $0.14 \mathrm{~g} \mathrm{~cm}^{-3}$ ), which would seem implausible for coniferous stands to confer in mere decades. In addition, much of the focus on tree species effects has focused on surface organic horizons, but given the symmetry in element ratios between mineral and forest floor substrates, we would argue that a true tree species effect should extend throughout the rooting zone of the soil profile.

\subsection{Regional significance of $P$ deficiencies}

With mean annual precipitation near $3500 \mathrm{~mm}$, these perhumid rainforests are at the extreme range in rainfall for the Pacific west coast (Carpenter et al., 2014). The evidence for P constraints outlined in this trial have been substantiated by fertilizer studies of very similar perhumid forests along northern Vancouver Island (Blevins et al., 2006; Negrave et al., 2007), but other areas in the Pacific Northwest have shown more variation in growth response to added $\mathrm{P}$ (Radwan et al., 1991; Mainwaring et al., 2014). Lower precipitation levels or differences in soil mineralogy could mediate rates of soil podzolization and reductions in $\mathrm{P}_{\mathrm{i}}$ so the full regional extent of these presumed $\mathrm{P}$ deficiencies should be examined and tested more thoroughly. We expected some utility in soil $\mathrm{N}: \mathrm{P}_{\mathrm{O}}$ as a measure of forest productivity (Wardle et al., 2004), but it is possible the mismatch in element thresholds for $\mathrm{N}$ and $\mathrm{P}_{\mathrm{o}}$ turnover, as discussed above, reduced the efficacy of this index. Ultimately, soil $\mathrm{C}: \mathrm{N}$ and soil $\mathrm{P}_{\mathrm{i}}$ together might best explain variations in rainforest productivity but the limitations in study size (64 plots distributed among four conifer species and three planting densities) prevented an adequate statistical analysis of all main factor interactions for two soil covariates. Phosphorus deficiencies are also relevant in the noted nutrient exchange between marine and terrestrial environments through anadromous salmon biomass (Cederholm et al., 1999). Our results support the likelihood that both salmon-derived $\mathrm{N}$ and $\mathrm{P}$ contribute to alleviating nutrient limitations of $P$. sitchensis on riparian sites of the Pacific west coast (Reimchen and Arbellay, 2019).

\section{Conclusions}

Quantifying the fundamental relationships between soil element ratios and conifer species productivity was facilitated in this study by the planting of single provenances at controlled densities, alongside a uniform macroclimate and narrow elevation band among plot locales. Soil organic matter content of perhumid rainforests was often high and displayed strong positive correlations in soil $\mathrm{C}, \mathrm{N}$ and $\mathrm{P}_{\mathrm{o}}$ concentrations. Inorganic $\mathrm{P}$ was generally in low supply, reflecting soil podzolization processes, and contributed a relatively minor proportion of total $\mathrm{P}$. Element ratios of $\mathrm{C}: \mathrm{N}$ and $\mathrm{C}: \mathrm{P}_{\mathrm{O}}$ were well correlated in forest floors and mineral soils, yet only $\mathrm{C}: \mathrm{N}$ was an effective measure of forest productivity and foliar nutrition. High $C: P_{o}$ ratios (as much as 3000) may reflect a stronger immobilization sink for $\mathrm{P}$ than $\mathrm{N}$, which, along with ongoing sorption of $\mathrm{PO}_{4}^{-}$, could limit the capacity of organic $\mathrm{P}$ turnover to meet tree requirements. The interplay of conifers and soils after 5 decades suggests species growth response to inherent soil $\mathrm{C}: \mathrm{N}$ was more intrinsic to ecosystem productivity than any reciprocal effects of tree species on soil resources. The conifers with ectomycorrhizal fungi had widely diverging responses in basal area over the $\mathrm{N}$ gradient, illustrating the extent of both competitive (Picea sitchensis) and stress-tolerant (Tsuga heterophylla, P. menziesii) traits for these tree species. The chemical nature and availability of soil $\mathrm{P}$ to trees, particularly as $\mathrm{P}_{\mathrm{o}}$, deserves further investigation as many of these perhumid rainforests were co-limited by both $\mathrm{N}$ and $\mathrm{P}$, or, in some stands, possibly $\mathrm{P}$ alone.

Data availability. All data related to the study are archived with Dryad at https://doi.org/10.5061/dryad.0gb5mkkwr (Kranabetter et al., 2019b). 
Supplement. The supplement related to this article is available online at: https://doi.org/10.5194/bg-17-1247-2020-supplement.

Author contributions. LdM was responsible for EP571 administration, including research site maintenance, tree measurements, and data archiving; JMK conceived study design for soil covariates; JMK and AS undertook field soil sampling and laboratory preparation; JMK and AS contributed statistical analysis; JMK wrote the manuscript with substantial contributions by AS and LdM.

Competing interests. The authors declare that they have no conflict of interest.

Acknowledgements. The planting density trial (EP571) was established by John Hetherington of the B. C. Ministry of Forests, Lands and Natural Resources in cooperation with British Columbia Forest Products Ltd. and MacMillan Bloedel Ltd. Plot maintenance and stand remeasurements over the many decades were managed by research personnel of the B.C. Ministry of Forests, Lands and Natural Resources, including Stephen Omule, Dave Paul, Lisa Meyer and Dave Goldie, plus a number of dedicated contractors. We thank Justin Meeds (University of UBC Okanagan) and Heather Klassen (B.C. Ministry of Forests, Lands and Natural Resources) for assistance in field sampling of soils and foliage. Laboratory analysis was undertaken by Kristopher Beaudet and Amber Sadowy of the B.C. Ministry of Environment Analytical Laboratory. Statistical advice was provided by Peter Ott (B.C. Ministry of Forests, Lands and Natural Resources).

Financial support. This research has been supported by the B.C. Ministry of Forests, Lands and Natural Resources.

Review statement. This paper was edited by Sönke Zaehle and reviewed by two anonymous referees.

\section{References}

Achat, D. L., Augusto, L., Gallet-Budynek, A., and Loustau, D.: Future challenges in coupled $\mathrm{C}-\mathrm{N}-\mathrm{P}$ cycle models for terrestrial ecosystems under global change: a review, Biogeochemistry, 131, 173-202, 2016.

Alberti, G., Vicca, S., Inglima, I., Belelli-Marchesini, L., Genesio, L., Miglietta, F., Marjanovic, H., Martinez, C., Matteucci, G., D’Andrea, E., Peressotti, A., Petrella, F., Rodeghiero, M., and Francesca Cotrufo, M.: Soil C:N stoichiometry controls carbon sink partitioning between above-ground tree biomass and soil organic matter in high fertility forests, Biogeosci. Forest., 8, 195206, 2015 .

Antoine, M. E.: An ecophysiological approach to quantifying nitrogen fixation by Lobaria oregana, Bryologist, 107, 82-87, 2004.

Antos, J. A., Filipescu, C. N., and Negrave, R. W.: Ecology of western redcedar (Thuja plicata): implications for management of a high-value multiple-use resource, Forest Ecol. Manag., 375, 211-222, 2016.

Augusto, L., Ranger, J., Binkley, D., and Roth, A.: Impact of several common tree species of European temperate forests on soil fertility, Ann. For. Sci., 59, 233-253, 2002.

Binkley, D.: The influence of tree species on forest soils: processes and patterns, in: Proceedings of the Trees and Soil Workshop, edited by: Mead, D. J. and Cornforth, I. S., Agronomy Society of New Zealand, Special Publication, 10, 1-33, 1995.

Binkley, D.: How nitrogen fixing trees change soil carbon, in: Tree species effects on soils: implications for global change, edited by: Binkley, D. and Menyailo, O., NATO Science Series, Kluwer Academic Publishers, Dordrecht, 155-164, 2005.

Bisbing, S. M. and D'Amore, DV.: Nitrogen dynamics vary across hydrologic gradients and by forest community composition in the perhumid coastal temperate rainforest of southeast Alaska, Can J. Forest Res., 48, 180-191, 2018.

Blevins, L. L., Prescott, C. E., and Niejenhuis, A. V.: The effect of phosphorus fertilization on nitrogen and phosphorus deficient sites on northern Vancouver Island, Forest Ecol. Manag., 234, 116-122, 2006.

Boczulak, S. A., Hawkins, B. J., and Roy, R.: Temperature effects on nitrogen form uptake by seedling roots of three contrasting conifers, Tree Physiol., 34, 513-523, 2014.

Booth, M. S., Stark, J. M., and Rastetter, E.: Controls on nitrogen cycling in terrestrial ecosystems: a synthetic analysis of literature data, Ecol. Monogr. 75, 139-157, 2005.

Brown, K. J. and Hebda, R. J.: Origin, development, and dynamics of coastal temperate conifer rainforests of southern Vancouver Island, Canada, Can. J. Forest Res., 32, 353-372, 2002.

Brown, K. R., Courtin, P. J., and Negrave, R. W.: Growth, foliar nutrition and $\delta^{13} \mathrm{C}$ responses of red alder (Alnus rubra) to phosphorus additions soon after planting on moist sites, Forest Ecol. Manag., 262, 791-802, 2011.

Bui, E. N. and Henderson, B. L.: C:N:P stoichiometry in Australian soils with respect to vegetation and evironmental factors, Plant Soil, 373, 553-568, 2013.

Cade-Menun, B. J., Berch, S. M., Preston, C. M., and Lavkulich, L. M.: Phosphorus forms and related soil chemistry of Podzolic soils on northern Vancouver Island, I. A comparison of two forest types, Can. J. Forest Res., 30, 1714-1725, 2000.

Carpenter, D. N., Bockheim, J. G., and Reich, P. F.: Soils of temperate rainforests of the North American Pacific Coast, Geoderma, 230/231, 250-264, 2014.

Carter, M. R. and Gregorich, E. G. (Eds.): Soil Sampling and Methods of Analysis, 2nd Edn., CRC Press, Taylor \& Francis Group, Boca Raton, Florida, 1224 pp., 2008.

Carter, R.: Diagnosis and interpretation of forest stand nutrient status, in: Forest fertilization: sustaining and improving nutrition and growth of western forests, edited by: Chappel, H. N., Weetman, G. F., and Miller, R. E., Institute of Forest Resources, No. 73, University of Washington, Seattle, 90-97, 1992.

Cederholm, C. J., Kunze, M. D., Murota, T., and Sibatani, A.: Pacific salmon carcasses: essential contributions of nutrients and energy for aquatic and terrestrial ecosystems, Fisheries, 24, 6$15,1999$.

Coates, K. D., Lilles, E. B., and Astrup, R.: Competitive interactions across a soil fertility gradient in a multispecies forest, J. Ecol., 101, 806-818, 2013. 
Cools, N., Vesterdal, L., De Vos, B., Vanguelova, E., and Hansen, $\mathrm{K}$.: Tree species is the major factor explaining $\mathrm{C}: \mathrm{N}$ ratios in $\mathrm{Eu}-$ ropean forest soils, Forest Ecol. Manag., 311, 3-16, 2014.

Darch, T., Blackwell, M. S. A., Chadwick, D., Haygarth, P. M., Hawkins, J. M. B., and Turner, B. L.: Assessment of bioavailable organic phosphorus in tropical forest soils by organic acid extraction and phosphatase hydrolysis, Geoderma, 284, 93-102, 2016.

DellaSala, D. A.: Temperate and boreal rainforests of the Pacific coast of North America, in: Temperate and Boreal Rainforests of the World: Ecology and Conservation, edited by: DellaSala, D. A., Island Press, Washington, DC, 42-82, 2011.

DeLuca, T. H., Glanville, H. C., Harris, M., Emmett, B. A., Pingree, M. R. A., de Sosa, L. L., Cerdá-Moreno, C., and Jones, D. L.: A novel biologically-based approach to evaluating soil phosphorus availability across complex landscapes, Soil Biol. Biochem., 88, 110-119, 2015.

Dickie, I. A., Koele, N., Blum, J. D., Gleason, J. D., and McGlone, M. S.: Mycorrhizas in changing ecosystems, Botany, 92, 149160, 2014

Edmonds, R. L. and Chappell, H. N.: Relationships between soil organic matter and forest productivity in western Oregon and Washington, Can. J. Forest Res., 24, 1101-1106, 1994.

Green, R. N. and Klinka, K.: A field guide to site identification and interpretation for the Vancouver Forest Region, Land Management Handbook 28, Crown Publications Inc, Victoria B.C., 285 pp., 1994.

Güsewell, S. and Gessner, M. O.: N : P ratios influence litter decomposition and colonization by fungi and bacteria in microcosms, Funct. Ecol., 23, 211-219, 2009.

Hawkins, B. J. and Kranabetter, J. M.: Quantifying inorganic nitrogen uptake capacity among ectomycorrhizal fungal species using MIFETM microelectrode ion flux measurements: theory and applications, Botany, 95, 963-969, 2017.

Hedin, L. O., Brookshire, E. N. J., Menge, D. N. L., Barron, A. R.: The nitrogen paradox in tropical forest ecosystems, Annu. Rev. Ecol. Evol. S., 40, 613-635, 2009.

Heuck, C. and Spohn, M.: Carbon, nitrogen and phosphorus net mineralization in organic horizons of temperate forests: stoichiometry and relations to organic matter quality, Biogeochemistry, 131, 229-242, 2016.

Hodge, A.: Accessibility of inorganic and organic nutrients for mycorrhizas, in: Mycorrhizal mediation of soil; fertility, structure, and carbon storage, edited by: Johnson, N., Gehring, C., and Jansa, J., Elsevier, Amsterdam, 129-148, 2017.

Hodgson, J. G., Wilson, P. J., Hunt, R., Grime, J. P., and Thompson, K.: Allocating C-S-R plant functional types: a soft approach to a hard problem, Oikos, 85, 282-294, 1999.

Homann, P. S., Harmon, M., Remillard, S., and Smithwick, E. A. H.: What the soils reveals: potential total ecosystem C stores of the Pacific Northwest region, USA, Foreset Ecol. Manag., 220, 270-283, 2005.

Jackson, D. A. and Somers, K. M.: The spectre of "spurious" correlations, Oecologia, 86, 147-151, 1991.

Keith, H., Mackey, B. G., and Lindenmayer, D. B.: Re-evaluation of forest biomass carbon stocks and lessons from the world's most carbon-dense forests, P. Natl. Acad. Sci. USA, 106, 1163511640, 2009.
Koele, N., Dickie, I. A., Oleksyn, J., Richardson, S. J., and Reich, P. B.: No globally consistent effect of ectomycorrhizal status on foliar traits, New Phytol., 196, 845-852, 2012.

Kranabetter, J. M.: Increasing soil carbon content with declining soil manganese in temperate rainforests: is there a link to fungal Mn?, Soil Biol. Biochem., 128, 179-181, 2019.

Kranabetter, J. M. and Banner, A.: Selected biological and chemical properties of forest floors across bedrock types on the north coast of British Columbia, Can. J. Forest Res., 30, 971-981, 2000.

Kranabetter, J. M., LePage, P., and Banner, A.: Management and productivity of cedar-hemlock-salal scrub forests on the north coast of British Columbia, Forest Ecol. Manag., 308, 161-168, 2013.

Kranabetter, J. M., Hawkins, B. J., Jones, M. D., Robbins, S., Dyer, T., and Li, T.: Species turnover ( $\beta$ diversity) in ectomycorrhizal fungi linked to $\mathrm{NH}_{4}^{+}$uptake capacity, Mol. Ecol., 24, 5992-6005, 2015.

Kranabetter, J. M., Harman-Denhoed, R., and Hawkins, B. J.: Saprotrophic and ectomycorrhizal fungal sporocarp stoichiometry $(\mathrm{C}: \mathrm{N}: \mathrm{P})$ across temperate rainforests as evidence of shared nutrient constraints among symbionts, New Phytol., 221, 482492, 2019a.

Kranabetter, J. M., Sholinder, A., and de Montigny, L.: Data from: Soil carbon, nitrogen and phosphorus stoichiometry $(\mathrm{C}: \mathrm{N}: \mathrm{P})$ in relation to conifer species productivity and nutrition across British Columbia perhumid rainforests, https://doi.org/10.5061/dryad.0gb5mkkwr, 2019b.

Lacourse, T.: Late Quaternary dynamics of forest vegetation on northern Vancouver Island, British Columbia, Canada, Quaternary Sci. Rev., 24, 105-121, 2005.

Lacourse, T.: Environmental change controls postglacial forest dynamics through interspecific differences in life-history traits, Ecology, 90, 2149-2160, 2009.

Lin, G.M., McCormack, L., Ma, C., and Guo, D.: Similar belowground carbon cycling dynamics but contrasting modes of nitrogen cycling between arbuscular mycorrhizal and ectomycorrhizal forests, New Phytol., 213, 1440-1451, 2017.

Lindo, Z. and Whiteley, J. A.: Old trees contribute bio-available nitrogen through canopy bryophytes, Plant Soil, 342, 141-148, 2011.

Littke, K. M, Harrison, R. B., Briggs, D. G., and Grider, A. R.: Understanding soil nutrients and characteristics in the Pacific Northwest through parent material origin and soil nutrient regime, Can. J. Forest Res., 41, 2001-2008, 2011.

Littke, K. M., Harrison, R. B., Zabowski, D., Briggs, D. G., and Maguire, D. A.: Effects of geoclimatic factors on soil water, nitrogen, and foliar properties of Douglas-fir plantations in the Pacific Northwest, Forest Sci., 60, 1118-1130, 2014.

Mainwaring, D. B., Maguire, D. A., and Perakis, S. S.: Three-year growth response of young Douglas-fir to nitrogen, calcium, phosphorus, and blended fertilizers in Oregon and Washington, Forest Ecol. Manag., 327, 178-188, 2014.

Manzoni, S., Trofymow, J. A., Jackson, R. B., and Porporato, A.: Stoichiometric controls on carbon, nitrogen, and phosphorus dynamics in decomposing litter, Ecol. Monogr., 80, 89-106, 2010.

McNicol, G., Bulmer, C., D’Amore, D., Sanborn, P., Saunders, S., Giesbrecht, I., Arriola, S.-G., Bidlack, A., Butman, D., and Buma, B.: Large, climate-sensitive soil carbon stocks mapped with pedology informed machine learning in the North Pacific 
coastal temperate rainforest, Environ. Res. Lett., 14, 014004, https://doi.org/10.1088/1748-9326/aaed52, 2019.

Menge, D. N. L. and Hedin, L. O.: Nitrogen fixation in different biogeochemical niches along a 120000 -year chronosequence in New Zealand, Ecology, 90, 2190-2201, 2009.

Mooshammer, M., Wanek, W., Schnecker, J., Wild, B., Leitner, S., Hofhansi, F., Blöchl, A., Hämmerle, I., Frank, A. H., Fuchslueger, L., Keiblinger, K. M., Zechmeister-Boltenstern, S., and Richter, A.: Stoichiometric controls of nitrogen and phosphorus cycling in decomposing beech leaf litter, Ecology, 93, 770-782, 2012.

Mooshammer, M., Wanek, W., Zechmeister-Boltenstern, S., and Richter, A.: Stoichiometric imbalances between terrestrial decomposer communities and their resources: mechanisms and implications of microbial adaptations to their resources, Front. Microbiol., 5, 10 pp., 2014.

Negrave, R., Prescott, C. E., and Barker, J. E.: Growth and foliar nutrition of juvenile western hemlock and western redcedar plantations on low- and medium-productivity sites on northern Vancouver Island: response to fertilization and planting density, Can. J. Forest Res., 37, 2587-2599, 2007.

O'Halloran, I. P. and Cade-Menum, B. J.: Total and organic phosphorus, in: Soil Sampling and Methods of Analysis, 2nd Edn., edited by: Carter, M. and Gregorich, E. G., Lewis Publishers, Boca Raton, Florida, 265-291, 2008.

Olander, L. P. and Vitousek, P. M.: Biological and geochemical sinks for phosphorus in a wet tropical forest soil, Ecosystems, 7, 404-419, 2004.

Omule, S. A. Y.: Early growth of four species planted at three spacings on Vancouver Island, FRDA Report 009, BC Ministry of Forests and Lands, available at: https://www.for.gov.bc.ca/hfd/ pubs/Docs/Frr/Frr009.htm (last access: 24 July 2015), 1988.

Parfitt, R. L., Ross, D. J., Coomes, D. A., Richardson, S. J., Smale, M. C., and Dahlgren, R. A.: N and P in New Zealand soil chronosequences and relationships with foliar $\mathrm{N}$ and $\mathrm{P}$, Biogeochemistry, 75, 305-328, 2005.

Perakis, S. S. and Pett-Ridge, J. C.: Nitrogen-fixing red alder trees tap rock-derived nutrients, P. Natl. Acad. Sci. USA, 116, 50095014, 2019.

Perakis, S. S. and Sinkhorn, E. R.: Biogeochemistry of a temperate forest nitrogen gradient, Ecology, 92, 1481-1491, 2011.

Perakis, S. S., Maguire, D. A., Bullen, T. D., Cromack, K., Waring, R. H., and Boyle, J. R.: Coupled nitrogen and calcium cycles in the forests of the Oregon Coast Range, Ecosystems, 9, 63-74, 2006.

Perakis, S. S., Sinkhorn, E. R., Catricala, C. E., Bullen, T. D., Fitzpatrick, J. A., Hynicka, J. D., and Cromack Jr., K.: Forest calcium depletion and biotic retention along a soil nitrogen gradient, Ecol. Appl. 23, 1947-1961, 2013.

Phillips, R. P., Brzostek, E., and Midgley, M. G.: The mycorrhizalassociated nutrient economy: a new framework for predicting carbon-nutrient couplings in temperate forests, New Phytol., 199, 41-51, 2013.

Prescott, C. E.: The influence of the forest canopy on nutrient cycling, Tree Physiol., 22, 1193-1200, 2002.

Prescott, C. E., Chappell, H. N., and Vesterdal, L.: Nitrogen turnover in forest floors of coastal Douglas-fir at sites differing in soil nitrogen capital, Ecology, 81, 1878-1886, 2000a.
Prescott, C. E., Vesterdal, L., Pratt, J., Venner, K. H., de Montigny, L. M., and Trofymow, J. A.: Nutrient concentrations and nitrogen mineralization in forest floors of single species conifer plantations in coastal British Columbia, Can. J. Forest Res., 30, 13411352, 2000b.

Preston, C. M. and Trofymow, J. A.: Characterization of soil P in coastal forest chronosequences of southern Vancouver Island: effects of climate and harvesting disturbances, Can. J. Soil Sci., 80, 633-647, 2000.

Radwan, M. A., Shumway, J. S., DeBell, D. S., and Kraft, J. M.: Variance in response of pole-size trees and seedlings of Douglasfir and western hemlock to nitrogen and phosphorus fertilizers, Can. J. Forest Res., 21, 1431-1438, 1991.

Reich, P. B. and Oleksyn, J.: Global patterns of plant leaf N and P in relation to temperature and latitude, P. Natl. Acad. Sci. USA, 101, 11001-11006, 2004.

Reimchen, T. E. and Arbellay, E.: Influence of spawning salmon on tree-ring width, isotopic nitrogen, and total nitrogen in oldgrowth Sitka spruce from coastal British Columbia, Can. J. Forest Res., 49, 1078-1086, 2019.

Sajedi, T., Prescott C. E., Seely, B., and Lavkulich, L. M.: Relationships among soil moisture, aeration and plant communities in natural and harvested coniferous forests in coastal British Columbia, Canada, J. Ecol., 100, 605-618, 2012.

Saggar, S., Parfitt, R. L., Salt, G., and Skinner, M. F.: Carbon and phosphorus transformations during decomposition of pine forest floor with different phosphorus status, Biol. Fert. Soils, 27, 197204, 1998.

Sanborn, P., Lamontagne, L., and Hendershot, W.: Podzolic soils of Canada: genesis, distribution, and classification, Can. J. Soil Sci., 91, 843-880, 2011.

SAS Institute Inc.: SAS/STAT ${ }^{\circledR} 9.4$ User's Guide, Cary, NC, USA, 550 pp., 2014

Singleton, G. A. and Lavkulich, L. M.: A soil chronosequence on beach sands, Vancouver Island, British Columbia, Can. J. Soil Sci., 67, 795-810, 1987.

Smithwick, E. A. H., Harmon, M. E., Remillard, S. M., Acker, S. A., and Franklin, J. F.: Potential upper bounds of carbon stores in forests of the Pacific Northwest, Ecol. Appl., 12, 1303-1317, 2002.

Soil Classification Working Group: The Canadian System of Soil Classification, 3rd Edn., Publ. 1646, Agriculture and Agri-Food Canada, Ottawa, ON, 164 pp., 1998.

Soudzilovskaia, N. A., Douma, J. C., Akhmetzhanova, A. A., van Bodegom, P. M., Cornwell, W. K., Moens, E. J., Treseder, K. K., Tibbett, M., Wang, Y.-P., and Cornelissen, J. H. C.: Global patterns of plant root colonization intensity by mycorrhizal fungi explained by climate and soil chemistry, Global Ecol. Biogeogr., 24, 371-382, 2015.

Spohn, M.: Element cycling as driven by stoichiometric homeostasis of soil microorganisms, Basic Appl. Ecol., 17, 471-478, 2016.

Sun, O. J., Campbell, J., Law, B. E., and Wolf, V.: Dynamics of carbon stocks in soils and detritus across chronosequences of different forest types in the Pacific Northwest, USA, Glob. Change Biol., 10, 1470-1481, 2004.

Thomas, K. D. and Prescott, C. E.: Nitrogen availability in forest floors of three tree species on the same site: the role of litter quality, Can. J. Forest Res., 30, 1698-1706, 2000. 
Tipping, E., Somerville, C. J., and Luster, J.: The C:N:P:S stoichiometry of soil organic matter, Biogeochemistry, 130, 117131, 2016.

Turner, B. L., Condron, L. M., Wells, A., and Andersen, K .M.: Soil nutrient dynamics during podzol development under lowland temperate rain forest in New Zealand, Catena, 97, 50-62, 2012.

Van Sundert, K., Horemans, J. A., Stendahl, J., and Vicca, S.: The influence of soil properties and nutrients on conifer forest growth in Sweden, and the first steps in developing a nutrient availability metric, Biogeosciences, 15, 3475-3496, https://doi.org/10.5194/bg-15-3475-2018, 2018.

Van Sundert, K., Radujkovic, D., Cools, N., De Vos, B., Etzold, S., Fernandez-Martinez, M., Janssens, I., Merila, P., Peñuelas, J., Sardans, J., Stendahl, J., Terrer, C., and Vicca, S.: Towards comparable assessment of the soil nutrient status across scales review and development of nutrient metrics, Glob. Change Biol., 26, 392-409, https://doi.org/10.1111/gcb.14802, 2020.

Vesterdal, L. and Raulund-Rasmussen, K.: Forest floor chemistry under seven tree species along a soil fertility gradient, Can. J. Forest Res., 28, 1636-1647, 1998.
Vitousek, P. M., Porder, S., Houlton, B.Z., and Chadwick, O. A.: Terrestrial phosphorus limitation: mechanisms, implications, and nitrogen-phosphorus interactions, Ecol. Appl., 20, 5-15, 2010.

Wang, T., Hamann, A., Spittlehouse, D. L., and Murdock, T. Q.: ClimateWNA - high-resolution spatial climate data for western North America, J. Appl. Meteorol. Clim., 51, 16-29, 2012.

Wardle, D. A., Walker, L. R., and Bardgett, R. D.: Ecosystem properties and forest decline in contrasting long-term chronosequences, Science, 305, 509-513, 2004.

Waring, R. H. and Franklin, J. F.: Evergreen coniferous forests of the Pacific Northwest, Science, 204, 1380-1386, 1979.

Xu, X., Thornton, P. E., and Post, W. M.: A global analysis of soil microbial biomass carbon, nitrogen and phosphorus in terrestrial ecosystems, Glob. Ecol. Biogeo., 22, 737-749, 2013.

Yang, X. and Post, W. M.: Phosphorus transformations as a function of pedogenesis: A synthesis of soil phosphorus data using Hedley fractionation method, Biogeosciences, 8, 2907-2916, https://doi.org/10.5194/bg-8-2907-2011, 2011.

Zechmeister-Boltenstern, S., Keiblinger, K.M., Mooshammer, M., Peñuelas, J., Richter, A., Sardans, J., and Wanek, W.: The application of ecological stoichiometry to plant-microbial-soil organic matter transformation, Ecol. Monogr., 85, 133-155, 2015. 